\title{
A Theory of the Competing Supply Chain: Alternatives for Development
}

\author{
Imoh Antai \\ Department of Supply Chain Management \& Corporate Geography \\ Hanken School of Economics \\ Arkadiankatu 22, 00101, Helsinki, Finland \\ Tel: 358-(0)40-352-1283Ｅ-mail: antai@hanken.fi
}

\begin{abstract}
Development of a coherent methodology for supply chain vs. supply chain competition remains elusive in literature in terms of purpose, approaches and theoretical foundations. The purpose of this paper is to identify suitable theories of competition from which supply chain vs. supply chain competition may be further developed. Paper explores literature on competition theories, competition and its correlates and also considers the dichotomy between competitiveness and competition in relation to achievement of a competitive advantage in supply chains. An argument is made for the identification and development of theory that reflects the multidimensional, process-based and emergent properties of supply chains. Three competition theories from which supply chain vs. supply chain competition may begin to be conceptualized and possibly operationalized are identified. A chronological conceptualization of competition, competitiveness and competitive advantage, which is intuitive to the realization of competitive advantage in inter-supply chain competition, is also proposed.
\end{abstract}

Keywords: Competition, Competitiveness, Competitive advantage, Competition theory, Dimensionality, Niche theory

\section{Introduction}

A supply chain is the network of organizations involved, through upstream and downstream linkages, in the different processes and activities that produce value in the form of goods and services for end-customers (Christopher, 1992). Most definitions of supply chain management succinctly divide the discipline into several parts. And the multi-disciplinary, multi-dimensional nature of supply chains and its management imply that there is hardly a single focus for supply chain management, which is essential for developing theory for supply chain vs. supply chain competition. That is to say, for the development of a supply chain competition theory, a clear explanatory purpose of competition between supply chains is needed. Determining an explanatory purpose for competition is complex mainly because supply chain management is seen both as a management discipline and as an operational subject. While reconciling these two views within supply chain management present significant challenges, it is the development of an (single) explanatory purpose of competition between supply chains that promises much fierce debates.

Hence, the purpose of this paper is to identify possible competition theories within which supply chain vs. supply chain competition may be properly conceptualized and perhaps subsequently operationalized. It also seeks to develop an understanding of competitive advantage in relation to competition and competitiveness given its importance to the notion of competition as a whole, and supply chain vs. supply chain competition in particular. A theory is regarded as a set of concepts used to define and/ or explain some phenomenon (Silverman, 2000). In general, it postulates structural relationships between key constructs (Trochim, 1989). Theory consists of plausible relationships produced among concepts and sets of concepts. And as Silverman (2000) puts it, without theory phenomena cannot be understood, hence without theory, there is nothing to research. If it is agreed that there is even a remote need to consider competition between supply chains, then it is also given that a purpose of such a competition is necessary. Thus, the identification of theories for possible modification and adoption in supply chain vs. supply chain competition represent first, albeit small, contribution towards this goal. In the apparent absence of a suitable theoretical basis for supply chain vs. supply chain competition, literature is reviewed with the aim of identifying competition theories sufficiently accommodating to this form of competition. On the other hand, by proposing an alignment of competition and its correlates, it is conceived that the process of competition and the dual states of competitiveness and competitive advantage are operational within the context of supply chain vs. supply chain competition.

\section{Background and theoretical considerations for competition}

The concept of supply chain vs. supply chain competition is no longer new to supply chain management literature. However, implicit questions surrounding the meaning of the concept, its usage and acceptance continues within supply chain management circles. Rice and Hoppe (2001) have noted the underlying difference of opinion within 
academia, industry and consulting regarding the meaning of supply chain vs. supply chain competition. Beyond the varied understandings of competition between supply chains proposed in literature, e.g. as complex adaptive systems (Langdon and Sikora, 2006), use of economic network model (Zhang, 2006), and on network capabilities (Rice and Hoppe, 2001), there is unwillingness within supply chain management scholars to debate the validity of the concept of supply chain vs. supply chain competition. This is based on the fact that there is little in the current literature to suggest that the ascribed meaning of such formulations as supply chain vs. supply chain competition is relevant and acceptable to the development of the discipline.

While conventional competition remains strong within management literature, the main difference between this form of competition and supply chain competition lie in the fact that firms cannot act as isolated, independent entities in competition with other organizations (Christopher, 1998). Open competition between organizations breed innovation, and innovation is the root of all economic progress (Cook, 2003). Hence, without competition there is little or no innovation. In supply chains, this innovation can be likened to the value each supply chain seeks to create for its end-customers, who remain the essence of the supply chain. Therefore competition between supply chains is necessary, and as such there is a need to understand and conceptualize such competition, because it exists.

Prior to considering possible theories, it is appropriate to underline the contexts upon which theories will be considered for supply chain vs. supply chain competition. This is important to establish the idea of the broader dynamics of change that continuously occur in supply chain management.

\subsection{Dimensionality}

Supply chains have been known to be quite complex especially with regards to competition. Given the extent to which supply chains may operate, competition between supply chains can be described as essentially multidimensional (Lancioni, 2000) especially in terms of the relationships it is connected to. Harrigan (1985) argue that supply chains are multidimensional and characterized by the different stages, breadth, form, degree and modes of integration it exhibits. In the same vein, Gardner (2004) makes a quantitative argument for the multi-dimensionality of supply chains. Supply chain management is primarily concerned with integration of position between several decision makers whose agents (manufacturers, suppliers, distributors, etc) are interested and specialized in a number of different areas. Thus, dimensionality represents a group of characteristics whose presence is necessary and sufficient to determine the unique function and character of a supply chain network. While these characteristics are unique to the supply chain, dimensions for supply chain efficiency may vary from supply chain to supply chain. For example, the Sand Cone model (Ferdows and Meyer, 1990) specifies several areas of manufacturing capabilities which should be developed on an incremental basis. Quality capabilities are developed first, followed by the dependability and subsequently the competence in speed is developed. Finally, the cost efficiency dimension is developed in order to maintain competitive performance. Dimensions are thus important as it allow entities decide along which aspect they will best succeed in the competition process. It also brings up aspects of specialization to competition issues.

\subsection{Process Orientation}

Supply chain management can be seen as a process based approach for identifying, evaluating, selecting, managing and developing value performance that is better than the competition (Monczka et al., 2009). The Global Supply Chain Forum (GSCF) identified eight supply chain management processes (Lambert, 2008); customer relationship management, supplier relationship management, customer service management, demand management, order fulfilment, manufacturing flow management, product development and commercialization, and returns management. By being process based, theory of competition is able to explain fairly accurately the dynamics of behaviour as they change over time. Process-based thinking represents a procedure by which the behaviour of a system is obtained from a set of interactions between entities and themselves and with the environment, through physical and mechanistic processes which occurs over time (Godfrey 1983). Hence, for the process-based criteria, behaviour is important to the understanding of competition.

\subsection{Emergence}

Competition between supply chains could also be regarded as emergent (Storey et al., 2006), along with other forms such as co-opetition and national competition whereby the behaviour causing competition arises from the interaction between supply chains for resources, innovation and advantage of particular sort. Building on the process orientation discussed above, emergence extends this idea to a logical conclusion by looking at interaction from the opposite end, i.e. in terms of results. Thus, emergence focuses on the behavioural outcome of interactions between entities and treats these outcomes as a result of the very same interaction between entities. Over time, this should allow certain outcomes to be expected of certain types of interaction and possibly vice-versa. Based on this, emergence expressly assumes that competition (competitive interaction) must involve more than one entity. To be accommodating to 
supply chain vs. supply chain competition, theories must place equal emphasis on process orientation as they do on emergence. For supply chains, doing this may be instrumental to understanding how some of the complexities of supply chains play in to affect how supply chains compete.

\section{Literature overview: Competition theories}

\subsection{Economic theory of competition}

From an economics perspective, the theory of competition essentially encompasses two broad ideas - 1). Competition as structure, in which firms within an industry strive for some kind of control of the forces determining equilibrium (demand and supply) within that industry. This type of competition, usually referred to as neoclassical, encompasses four main theoretical competition thoughts: perfect competition, monopolistic competition, oligopoly and monopoly (Lipczynski et al., 2005). These theories underline the idea of competition within the industrial organization context generally regarded as the static view of competition (Lipczynski et al., 2005). Traditionally, industrial competition had been that which was carried out on the basis of the economic power of large firms and their ability to generate economies of scale allowing goods to be produced at low unit costs (Best, 1990). From the contemporary point of view however, flexible technologies, e.g. information technology, advances in communication technologies, computing, etc, have allowed the substitution of economies of scale by economies of scope, where emphasis on innovation rather than low unit cost, collaborations rather than scale enterprise, and export rather than foreign investment, dominate such industrial systems (Best, 1990; Gertler and Barnes, 1999). And 2). Competition as a process, whereby the struggle essentially focuses on the behaviour of firms, actors, etc within the market, which ultimately establishes how much rivalry exists within the industry (Metcalfe, 1998). This more dynamic position of competition was argued by Schumpeter (1942) and the Austrian school (of economists). According to Schumpeter, the competitive process creates patterns of change, and change is driven by innovation; hence competition is determined by the amount of innovation that is created in the market. It challenges firms to compete in entirely new ways. The Austrian school, however, considers this dynamic process in terms of resource owners, entrepreneurs and customers (Kirzner, 1997). In this sense, entrepreneurs discover and act on new pieces of information which in turn acts to affect, by way of adjustment, the outcomes of other decision makers in the process.

However, the concept of perfect competition remains the standard model of analysis within the economics discipline. Over time the idea of competition in economics had began to shift its basis from perfect competition and the structural (equilibrium) ideology towards the process concept of competition (Metcalfe, 1998; Cook, 2003: 64-65). Loasby (1982) argued that intensity of competition is not dependent on the number of competitors in a given market because increasing numbers of competing firms only create an increasing scope for differential behaviour in the market. This change from static to dynamic competition has come to be known in literature as the hypercompetitive shift (D’Aveni, 1994), chararcterisized by improving technology, improved skill base of firms and its employees, more sophisticated demand, falling barriers to entry and increase in alliances and collaborations between firms (Thomas, 2001).

\subsection{Resource-Advantage (RA) theory of competition}

The R-A theory of competition can be seen to have its underpinnings in a number of sources, concepts and theories. In terms of concepts (i.e. competition), R-A draws profound inspiration from the neoclassical idea of perfect competition, where perfect competition is said to be incorporated into R-A theory as a limiting, special case of competition (Hunt and Morgan, 1996). R-A theory also utilizes Schumpeterian ideals of endogenous innovation customary in evolutionary economics, as well as influences from Austrian economics (Hunt, 2000). For theories, R-A looks to the combination of the resource based theory (Conner and Prahalad, 1996; Barney, 1986, 1991) and the marketing theory of heterogeneous demand to form its core notions (Hunt, 2002). The Resource-Advantage (R-A) theory according to Hunt (2007) is an evolutionary, disequilibrium provoking, process theory of competition, where innovation and management knowledge are endogenous, organizations and customers have inadequate information and one in which the environment (via free enterprise, organization and public policy) affect economic performance. It is a process theory that bases competition between entities on market segments and resources, both of which tend to influence organizational behavior (Goh, 2003). Market segments are intra-industry identifiable clusters of consumers which can be identical within clusters, but vary considerably across clusters. Resources on the other hand are the hard and soft assets available to the firm that makes it possible to efficiently produce offerings that have value for some market segments (Hunt, 2000). Cash, equipment, licenses/patents, skills, knowledge, cultures, etc are all examples of resources. Since such resources tend to vary significantly across firms (because most of these resources cannot be readily bought and sold in the marketplace), the concept of comparative advantage is central to R-A theory of competition. Comparative advantage is the ability of a firm to engage in the production of market offerings at a lower cost and with superior value, relative to extant offerings by competitors as a result of the 
resource assortment available to that firm (Goh, 2003). Thus, within R-A theory, competition encompasses a continuous struggle and search for resources that will allow firms the ability to claim comparative advantages. This yields a market place position of competitive advantage and consequently superior financial performance (Goh, 2003).

As such R-A theory infers that market place positions (i.e. positional advantage) determine the intensity of superior performance. A positional advantage within the R-A theory is the occupation of one of three advantage (2, 3 and 6$)$ cells out of a matrix of nine possible competitive positions. The cells reflect the possible combination of a firm's relative resource produced value against the relative resource costs for producing such value (Hunt, 2000). Value refers to the sum total of all benefits that consumers perceive they will receive if they accept a firm's market offerings (Hunt, 2000). The aim with the matrix is to occupy one of the three advantage cells, as those firms occupying other cells constantly struggle to reach one of these advantage cells.

\subsection{Ecological niche theory of competition}

The theory of niche takes as its area of jurisdiction the co-existence and competition for similar scarce resources between contending species. Over time, the niche theory of competition has become synonymous with competition theory (Colwell, 1999; Alley, 1982) which has largely come about as a result of its history with competition theory rather than logic. The development of the work known and called niche theory was started by Robert MacArthur and Richard Levins (1967). This work mainly focused on reinterpreting the competitive exclusion principle. The competitive exclusion principle formally states that "no two organisms in a single species can occupy precisely the same niche, or exist on exactly the same limiting resources" (Grinnell, 1917). What this principle simply assumes is that the coexistence of any two species implies that they must not be in true competition, because as the principles states, no two species can exist on the same limiting resources. Thus, the ultimate result of the principle of competitive exclusion is extinction. However, the works of MacAuthur and Levins (1967) introduced the idea of a limiting similarity between two competing species. This idea of limiting similarity suggested that the more similar two competing species are, the less likely it is that they will coexist. It is on this notion of similarity that the niche theory of competition finds its basis for competition, by using such concepts as niche breadth and niche overlap. Based on the principle of competitive exclusion, a niche is defined as the extent of environmental variation, in both biotic and abiotic factors, under which a species can engage in activities necessary for its survival (Alley, 1982). In this sense, species are viewed to have a multidimensional relationship with the environment. A niche breadth is thus the range of environmental conditions (including resources) within which a species can survive. It refers to the position occupied by a species on a particular resource dimension. When these niches overlap, the idea of similarity discussed above is brought into play. Thus, when two species vie for the same food resources, they have a limiting similarity, which means that their niches overlap and as such they become competitors because they cannot coexist ad infinitum. It provides a measure of ecological similarity between interacting species. Therefore competition, under the niche theory, is a resource-related form of interaction between two or more species (Birch, 1957). The following sections discuss competition and its correlates and thereof attempt an alignment that seeks to further elucidate the broader relationship between these three terms for supply chain vs. supply chain purposes.

\subsection{Aligning competition and its correlates}

\subsubsection{Competition}

Competing concepts of competition abound in a variety of disciplinary literature. However, a well established meaning of the competition concept is still vague, despite its extensive use as one of the core concepts of economic theory (Metcalfe, 1998; Telser, 2007: xiv). The nature of a theory of competition will depend, to a large extent, on the explanatory purpose in view, with respect to the idea being conceptualized (Cook, 2003). Hence, competition as originating from within different disciplinary frameworks would differ markedly. Theories of competition designed to elucidate the utilization of resources by competing entities will be reasonably different from one that promotes the idea of stability of structures that are essential to the control of resources in a given market. Any consideration of a competition theory for supply chain vs. supply chain competition must be informed by an understanding of the long standing debate between competition and its correlates - competitive advantage and competitiveness. Issues of consideration essentially include the relationship between these three terms. How does competitive advantage come about? Does it have anything to do with competition? However, the important question here remains that if we are to align competition, competitive advantage and competitiveness for supply chain vs. supply chain competition, what chronological order would accompany such an alignment?

\subsubsection{Competitiveness}

While competitiveness is widely used in literature, no clear definition of competitiveness has been agreed on, even with reference to an entire economy. The World Competitive Yearbook (WCY) defines competitiveness as: 
"a field of economic knowledge, which analyses the facts and policies that shape the ability of a nation to create and maintain an environment that sustains more value creation for its enterprises and more prosperity for its people".

Although comprehensive for its purpose, this definition remains cumbersome and fuzzy, and possessing no proper basis for testable propositions (Hagen and Immerfall, 1998), competitiveness remains elusive in literature (Wignaraja, 2003). However, Cho (1998) goes on to illustrate the concept of competitiveness in a more comprehensible and straightforward manner, as being "the relative strength that one needs to have to win in a competition against competitors".

Competitiveness discussions in literature have tended to focus on three different levels comparison - firm competitiveness, industry competitiveness and competitiveness of nations (Cho, 1998). It has also been described as a relative concept used to compare economic performance between these three levels (Dunning, 1997; 227). This economic performance is usually expressed at the national level in terms of national productivity (e.g. via the Gross Domestic Product (GDP), Foreign Direct Investment, trade balances, etc). This view in essence proposes comparisms between like entities, e.g. firm-firm, region-region, industry-industry, nation-nation comparisons, etc. There is a broad recognition that competitiveness of nations is essentially made up of the competitiveness of individual firms within that nation (Cho, 1998; Porter, 1990). As such, sources of competitiveness may be said to be identical for both categories of competitiveness. Meanwhile, Krugman (1994) sees the concept of competitiveness as meaningless and just another name for productivity, when applied to competitiveness of nations.

\subsubsection{Competitive advantage}

The concept of competitive advantage is a well-known notion whose essence has, however, been poorly understood (Hao Ma, 2000), especially with respect to supply chains and its management. The conceptualizations of competitive advantage across different literature streams convey three basic ideas.

The first notion of competitive advantage is one that promotes the resource-based view as the premise within which organizations can achieve competitive advantage. The resource based theory attempts to predict the outcome of competition by utilizing information on the resource utilization of competitors (Tilman, 1982). This view is very much regarded as the leading theory of competitive advantage, and much of it rests on the concept of heterogeneity of resources (Peteraf, 1993; Barney, 1991; Grant, 1991; 1986; Rumelt, 1987, 1984). Heterogeneity of resources is to a good extent is explained by Barney's (1991) conditions for achieving competitive advantage. The basic assumption of heterogeneity is that resources and capabilities that enable production are heterogeneous across firms (Barney, 1991).

The second notion of competitive advantage is one that advances the idea that the creation of value, which surpasses that created by rivals, provides a means of achieving competitive advantage. Porter (1985) argues that "competitive advantage grows fundamentally out of value a firm is able to create for its buyers that exceeds the firm's cost of creating it." In the same vein, Mentzer (2004: 7) asserts that competitive advantage can be achieved by creating value, for the end-customers, which is greater than that offered by competitors (Mentzer, 2004; Wilding and Newton, 1996). This view of competitive advantage is also alluded to by Ma (2000), asserting that competitive advantage is simply the differential between competitors on any given dimension, which allows one to better create customer value than the other.

The third conceptualization of competitive advantage is one that is based on profitability, implying that if a firm remains profitable for any period of time, it has to be doing something better than its competitors. Grant (2004) describes competitive advantage as the resulting potential profitability or higher rates of profit that accrues to one firm when two or more firms compete within the same market. This definition describes competitive advantage in terms of profitability, which is a widely held view in practitioner circles as firms would expressly assume a competitive advantage with increasing growth of profitability. In order to gain competitive advantage, some form of imperfection to competition must exist (Grant, 2004; 237). Conversely, Porter (1985) suggests that the structure of the industry, together with its competitive advantage ultimately determine how profitable a firm will be. Grant (2004), however alludes to the troublesome nature of defining competitive advantage with respect to profitability, arguing that if competitive advantage were a proxy for profitability there would be no need for the term competitive advantage. According to Grant (2004) there is more to competitive advantage than just profitability, which may not only be revealed in higher profits, for example market share, technology, intellectual capital, etc.

(Figure 1 about here)

Hence, literature on competitive advantage reveals that competitive advantage can be achieved by a combination of three factors - (1) Resources (2) Innovation and research \& development and (3) Cost leadership and differentiation (Fig. 1). Literature has also showed that competitive advantage may be sought for a number of reasons of which the 
most common tend to be profitability, performance, market share, value creation or a combination of these. Thus, the framework presented in Fig. 1 depicts a realistic picture of the antecedents of competitive advantage made up in part by innovation and research $\&$ development, resources and differentiation.

\section{Analysis and results}

\subsection{Relationship between the three Cs}

The following analysis of competition and its correlates presents a fundamentally different starting point from which they may be understood - the Supply chain. It challenges the commonly touted assumption that competitiveness is a means by which competitive advantage is achieved in supply chain management. This paper adopts the definition of competitiveness by Cho (1998), where it is regarded as the relative strength (ability) that is needed to engage and possibly win in a competition against rivals. Competitive advantage is the advantage, in value terms, a supply chain creates for its customers that essentially accrue from the competition with other supply chains. This definition emphasizes the fact that competitive advantage results from competition. In taking up the difference between competition and competitiveness, table 1 summarizes the variation between the terms. While competitiveness can be seen as a relational term, approaches to its treatment obviously differ from one to the other (Metcalfe et al., 2004). When the unit of analyses are countries or even industries, the issue of competitiveness is usually said to revolve around the relative position, strength, achievements, etc, of one with respect to the other. Thus, there is no standard. However, within supply chains, it essentially involves the ability of supply chains to gain competence. This competence is made up of the supply chain's ability to obtain resources and to put these resources to use in terms of producing profitable output. Thus, competitiveness demands efficient use of resources and efficacy of productivity from these resources.

(Table 1 about here)

On the other hand, competition is a process by which different entities strive for limited critical resources; customers, production resources, profit, market share, etc. Competition, from almost all concepts, essentially remains a process which changes over time, and involves the ability of one entity to be more efficient than another in acquiring and using resources that are essential to creating some form of value for itself and its ultimate end-customer. Thus, competition has been described as non-static and the dynamic nature of competition can be observed in the structural characteristics of the industrial organization concept of competition. This is quite similar to the Schumpeterian perspective of competition in terms of innovation and technological advancement. Thus, competition can be said to connote a different idea from that of competitiveness, given the differences that are apparent between the two concepts from literature. Accordingly, if competitiveness and competition connote different ideas, competitiveness par se, cannot be solely responsible for competitive advantage in supply chains, as frequently proposed in supply chain literature. Rather, there seems to be a continuum between competitiveness and competition, whereby competitiveness determines how well a supply chain is suited for competitive interaction (i.e. competition) and consequently determines which supply chain is more capable of using its resources in such a way as to lead to a competitive advantage.

\section{(Fig. 2 about here)}

Hence, the framework in Fig. 2 is divided into three stages corresponding to the continuum that is expected to occur between the three concepts. It entails that in order for supply chains to achieve competitive advantage, some form of competition has to be undertaken. Because competition does not exist as state of nature, the framework depicts competitiveness as the willingness and the ability of a supply chain to voluntarily take part in competition through which competitive advantage is either achieved or a return to the competitiveness state subsequently occurs. Thus, the essence of competitiveness within this framework is therefore to be described as the preparatory stage, while competition could be referred to as the interaction stage. The competitive advantage is referred to as the advantage stage. Therefore, any characterization of competitive advantage from a strategic perspective within supply chains should clearly be inseparable from a broader understanding of the dynamics between competitiveness and competition.

From literature, we understand that creating value is the purpose of supply chains (Mentzer, 2004), and this is done in a way that suggests that value which surpasses competitors' value offerings essentially make up the competitive advantage of that supply chain. Thus, based on the forgoing, our understanding of value with respect to competitive advantage can be distinguished into two categories for competition purposes - competition-based advantage, and a somewhat opposite term, competition-free value. Competition-based advantage is based on the idea that competitive advantage is achieved as an outcome of a head-to-head competition for scarce critical resources between two or more entities (e.g. Porter, 1985). On the other hand, competition-free value is value created by supply chains in which there is no competitive interaction (competition) from one end of the supply chain to the other with other 
related supply chains (e.g. Grant, 2004) . As such there is no connotation to an advantage within this mode of value creation.

\subsection{Implications for supply chain competition}

In previous sections, a review of literature identified current competition theories that might be suitably adapted to competition between supply chains, as well as the relationship that unite competition and its correlates. However, while important for the intended purpose, per se they do not provide perspective significance for supply chain competition. This section evaluates these data to determine potential implications for supply chain competition.

\subsubsection{Economic theory perspective}

Supply chain vs. supply chain competition from an economic theory perspective presents a number of challenges. The two perspectives of competition embedded and discussed within this theory make a comprehension of its application to supply chain vs. supply chain competition a little complicated. While on the one hand, economic theory of competition is guided by structural tendencies, which seeks to maintain equilibrium between the market forces of demand and supply. Known to be static in nature, most treatment of competition within this area assumes equilibrium conditions, as equilibrium constitute fundamental parts of many competition concepts. However, different competition concepts treat equilibrium differently. With the evolution of supply chain vs. supply chain competition, equilibrium conditions for competition become problematic especially as a proper basis for competition between supply chains is yet to be developed. On the other hand, the gradual reception of behavioural or process views of competition between entities allows for a more realistic context from which supply chain competition may be analysed. This view dissociates itself from most of the assumptions of perfect competition including equilibrium. Also, given this shift in perception, a discussion on the issue of supply chain vs. supply chain competition within the economic theory may begin.

\subsubsection{Niche theory perspective}

The competition here explores the limiting similarity between competing species based on the fact that diversity can be limited in at least three ways- the lower limit to abundance, the upper limit to abundance and lastly limits to specialization set by the environment (MacArthur and Levins, 1976). It is this limit to the degree of specialization that determines the limits to similarity of competing species. Therefore theories of niche can be used to analyze the interaction between different supply chains. The ecological niche theory of competition therefore presents a metaphor that can be adopted by other domains in an effort to elucidate complex issues between two or more entities. It does this via the concepts of interaction, niche and overlap. In the niche theory, a condition for competition is the existence of some similarity or overlap in niches of entities; this is clearly advocated within the niche literature. Because competition breeds diversification, it represents the shifting of niches, and hence provides proof that competition actually takes place. Thus, the niche competition theory emphasizes specialization and hence competition in dimensions.

\subsubsection{The R-A theory perspective}

R-A theory introduces the idea of resources as the mainstay of competitive achievement and maintains that within an industry, there are market segments and there are resources that are used to satisfy the market segments. The idea of the R-A theory is simple and straightforward. In order for firms to achieve a competitive advantage it must possess resources that other competing entities do not. In other words, the laws of comparative advantage must be obeyed. However, since the R-A theory practically theorizes competition in one dimension, handling the multidimensionality of supply chains within such theory could become cumbersome. The R-A theory goes further to suggest the concept of positional advantage which in effect can determine the competitive advantage of a firm and consequently superior financial performance by the positions firms take up within the industry. The global supply chain view transcends borders and industries (depending on how large the view of the industry is taken, e.g. regional industry). Hence the environment that acts to affect supply chains change with movement from upstream through the downstream of the supply chain. So for supply chains, competition will have much to do with the environment and the dimension upon which it takes place. Table 2 presents the identified competition theories and how they perform against the chosen supply chain criteria.

(Table 2 about here)

Based on the idea that competition is the driving force of the ruling structure in the industry, the relationship depicted by fig. 2 can be further extended to reflect this consideration, from a hierarchical point of view. Fig. 3 illustrates the idea of hierarchical ordering of competitively interactive supply chains according to the level and assets they seek to achieve. At the bottom of the pyramid supply chains that are neither interested nor capable of carrying on competitive interaction would occupy this level. Supply chains at this level do not make significant 
efforts to improve on areas that would be necessary for supply chains to have for competition purposes. Thus, supply chains at this level are simply referred to as "status quo" or "do nothing" supply chains.

On the competitiveness level supply chains strive to develop competencies that would be necessary in order for them to engage in competitive interaction. Here, special skills and competencies are developed (based on the heterogeneity of resources), ruling knowledge in the market are sought, regulations are identified, etc. Active developments in these areas are beneficial for supply chains as they inadvertently prepare for competitive interaction. On the competition level, this is where competition would actually take place and the rewards sought could include resources in the form of suppliers, raw materials, technology, patents, etc. At this level, competitive interaction takes place between supply chains. At the top level, supply chains that maintain leading positions within their industry occupy this level. The higher a supply chains goes on the pyramid, the better value such a supply chain is able to create for its end-customers, and hence there is a constant struggle to reach the top of the pyramid where it is possible to enjoy superior performance, larger market share, superior value creation abilities, etc. Arrows between the levels signify the possible movements of supply chains between levels, as supply chains that lose a position at the top of the pyramid would drop to the competition level where it would continue to seek a return to the top of the pyramid.

\section{(Figure 3 about here)}

In the foregoing, a conceptual relationship is ascertained between the concepts of competition, competitiveness and competitive advantage, and in so doing establish competition as an all important mediator between competitiveness and competitive advantage. Thus, it is logical that competition is seen to be a major driver of competitive advantage. This is simply so because based on the development of competition and competitiveness here, competition (competitive interaction) must be undertaken if competitive advantage is to be achieved.

\section{Conclusion}

The sole purpose of engaging in competition is to achieve and where possible, maintain a competitive advantage over competitors. This paper has firstly concerned itself with the search for suitable competition theories with which supply chain vs. supply chain competition may begin to be conceptualized in literature. Three candidate theories Economic, niche and R-A theories of competition - with varying characteristics were identified and subsequently compared against the properties of multi-dimensionality, process orientation and emergence. While the three theories showed similarity in a number of areas, they are regarded as different in that they emanate from totally different conceptual bases. Economic competition emphasises competition as its main driving force, niche theory advocates structure as the essence of competition, while R-A theory is solely based on the idea of comparative advantage of resources.

Second, the paper tackles the troublesome practice of equating the notions competitiveness and competition, and argues that competitiveness is not the sole antecedent of competitive advantage. To properly characterize and understand competitive advantage in supply chains requires an apposite context within which supply chain competition is conceptualized. That is to say, a basic framework from which we may begin to analyse the characteristics of supply chains, is important and of which competition is a part of. Because supply chains are unique (Cooper and Ellram, 1993), it is important that the competitive advantage context within which supply chain is discussed truly reflects its nature and the competition emanating thereof. Quite like competition, competitiveness per se is a necessary but insufficient condition for achieving competitive advantage; it represents a static process while competition depicts more of a dynamic process in many of its characteristics. Thus, to achieve competitive advantage, the processes of competitiveness and competition must be complementary in this undertaking. The differentiation between competition and competitiveness in terms of supply chains' achievement of competitive advantage serves to position competitiveness as input and competition as a mediator that acts to affect the outcome, competitive advantage.

Based on the conceptual review, the findings of this paper with regards to identifying suitable theories with which we may begin to analyze supply chain vs. supply chain competition represent only the first steps towards identifying a suitable theory for supply chain competition. Further research into examining the suitability of the theories identified herewith (and possible addition of new theories) would be a good place to start dealing with the question. Actual conceptualizations and operationalizations of supply chain vs. supply chain competition using identified theories would be interesting and essential contributions to the development of theory for inter-chain competition. Moreover, a cogent basis for supply chain competition would serve to further veer the interest of business practitioners more towards supply chain management and the competition which it espouses.

Although varying theories of competition exist, the competitive environment is constantly changing yet the mainstay of competition which is to compete, remains static. Regardless of the perspective with which competition is looked 
at, there is a need for competing entities to physically engage in interaction, which is borne out of the need to obtain some sort of resources or service that are generally scarce. The way and manner this interaction occurs and the outcome of such interaction is important, as it can determine how the conceptualization of supply chain competition may be advanced.

\section{References}

Alley, T. R. (1982). Competition theory, evolution, and the concept of an ecological niche. Acta Biotheoretica, 31, 165-179.

Barney, J. B. (1991). Firm resources and sustained competitive advantage. Journal of Management, 17, 99-120.

Barney, J. B. (1986). Strategic factor markets: Expectations, luck and business strategy. Management Science, 32, 1231-1241.

Best, M. H. (1990). The new competition. Cambridge, MA: Harvard University Press.

Birch, L. C. (1957). The meanings of competition. American Naturalist, 91, 5-18.

Cho, D. (1998). From national competitiveness to bloc and global competitiveness. Competitiveness Review, 8, $11-23$

Christopher, M. (1992). Logistics and supply chain management. Pitman, London.

Christopher, M. (1998). Logistics and Supply Chain Management: Strategies for Reducing Cost and Improving Service. Harlow: Prentice Hall, 2nd. ed.

Colwell, R. K. (1999). Niche: A bifurcation in the conceptual lineage of the term. In Keller, E. F. \& Lloyd, E. A. (Eds) Keywords in evolutionary biology. Harvard College Press.

Conner, K. \& Prahalad, C. K. (1996). A resource-based theory of the firm: Knowledge versus opportunism. Organization Science, 7, 477-501.

Cook, P. (2003). Competition and its regulation in developing countries. In Kirkpatrick, C., Clarke, R. \& Polidano, C. (Eds.) Handbook on development policy and management. Edward Elgar, UK.

Cooper, M. C., and. Ellram, L. M. (1993). Characteristics of Supply Chain Management and the Implications for Purchasing and Logistics Strategy. The International Journal of Logistics Management, 4, 13-24.

D'Aveni, R. A. (1994). Hypercompetition: Managing the dynamics of strategic manoeuvring. Free Press, New York.

Dunning, J. H. (1997). Alliance capitalism and global business. 1 ed. Routledge; London.

Ferdows, K. \& De Meyer, A. (1990). Lasting improvement in manufacturing performance: In search of a new theory. Journal of Operations Management, 9, 168-184.

Gardner, D. L. (2004). The supply chain vector: Methods for linking the execution of global business models with financial performance. J. Ross Publishing, Boca Raton, USA.

Gertler, M. S., \& Barnes, T. J. (1999). New industrial geography: Regions, regulations and institutions. Routledge.

Godfrey, K. (1983). Compartmental models and their applications. Academic Press, New York, NY.

Goh, J. P. (2003). The resource advantage theory of competition: Implications for higher educational institutions in Singapore. Educational Research for Policy and Practice, 2, 93-106.

Grant, R. M. (2004). Contemporary strategy analysis. Blackwell Publishers, MA, USA.

Grant, R. M. (1991). A resource based perspective of competitive advantage: Implications for strategy formulation. California Management Review, 33, 114-135.

Grinnell, J. (1917). The niche-relationships of the California thrasher. The Auk, 34, 427-433.

Hagen, J. V. \& Immerfall, S. Eds (1998). Territoriality in the globalizing society: One place or none. Springer, New York.

Harrigan, K. R. (1985). Vertical integration and corporate strategy. Academy of Management Journal, 28, 397-425.

Hunt, S. D. \& Morgan, R. M. (1996). The Resource-Advantage Theory of Competition: Dynamics, Path Dependencies, and Evolutionary Dimensions. Journal of Marketing, 60, 107-114.

Hunt, S. D. (2000). A general theory of competition: Resources, competences, productivity, economic growth. Sage Publications, USA. 
Hunt, S. D. (2002). Foundations of marketing theory: Toward a general theory of marketing. M. E. Sharpe Inc. USA.

Hunt S. D. (2007). Economic growth: should policy focus on investment or dynamic competition? European Business Review, 19, 274-291.

Kirzner, I. M. (1997). Entrepreneurial Discovery and the Competitive Market Process: An Austrian Approach. Journal of Economic Literature, 35, 60-85.

Krugman, P. (1994). Competitiveness: A dangerous obsession. Foreign Affairs, 73 (2), 28-44.

Lambert, D. M. (2008). Supply chain management, In Lambert, D. M. (Ed.) Supply chain management: Processes, partnerships, performance. Supply Chain Management Institute, USA.

Lancioni, R. A. (2000). New developments in supply chain management for the millennium. Industrial Marketing Management, 29, 1-6.

Langdon, C. S. \& Sikora, R. T. (2006). Conceptualizing co-ordination and competition in supply chains as complex adaptive systems. Information Systems and E-Business Management, 4, 71-81.

Loasby, B. (1982). The entrepreneur in economic theory. Scottish Journal of Political Economy, 29, 235-245.

Lipczynski, J., Wilson, J. O. \& Goddard, J. (2005). Industrial organization: Competition, strategy, policy. Pearson Education, UK.

Ma, Hao (2000). Competitive advantage and firm performance. Competitiveness Review, 10, 15-32.

MacArthur, R. \& Levins, R. (1967). The limiting similarity, convergence and divergence of coexisting species. American Naturalist, 101, 377-385.

Mentzer, J. T. (2004). Fundamentals of supply chain management: Twelve drivers of competitive advantage. Sage Publications, Inc.

Metcalfe, J. S. (1998). Evolutionary economics and creative destruction. Rutledge, London.

Metcalfe, J. S., Ramlogan, R. \& Uyarra, E. (2004). Competition, innovation and economic development: The instituted connection, In Cook, P., Kirkpatrick, C., Minogue, M. and Parker, D. (Eds.) Leading issues in competition, regulation and development. Edward Elgar Publishing, UK.

Monczka, R. M., Handfield, R. B. \& Giunipero, L. (2009). Purchasing and Supply Chain Management. Cengage Learning, USA.

Peteraf, M. A. (1993). The cornerstones of competitive advantage: A resource-based view. Strategic Management Journal, 14, 179-191.

Porter, M. E. (1985). Competitive advantage: Creating and sustaining superior performance. The Free-MacMillan Press.

Porter, M. E. (1990). The competitive advantage of nations. Free Press, NY.

Rice Jr., B. R. \& Hoppe, R. M. (2001). Supply chain vs. supply chain. The hype and the reality. Supply Chain Management Review Sept/Oct, 46-54.

Rumelt, R. P. (1984). Toward a strategic theory of firm. In Lamb, R. (Ed), Competitive Strategic Management, Prentice Hall, Englewood Cliffs.

Rumelt, R. P. (1987). Theory, strategy and entrepreneurship. In Teece, D. (Ed), The Competitive Challenge, Cambridge, MA: Ballinger.

Schumpeter, J. A. (1942). Capitalism, Socialism, and Democracy. New York: Harper and Brothers.

Silverman, D. (2000). Doing qualitative research. SAGE London.

Storey, J. Emberson, C., Godsell, J. \& Harrison A. (2006). Supply chain management: Theory, practice and future challenges. International Journal of Operations \& Production Management, 26, 754-774.

Telser, L. G. (2007). Competition, collusion, and game theory. Aldine Transaction, USA.

Thomas, L. G. (2001). The Japanese pharmaceutical industry: The new drug lag and the failure of industrial policy. Edward Elgar, UK.

Tilman, D. (1982). Resource competition and community structure. Princeton University Press. 
Trochim, W. K. (1989). Outcome pattern matching and program theory. Evaluation and Program Planning, 12, 355-366.

Wignaraja, G. (2003). Competitiveness strategy in developing countries. Routledge, London.

Wilding, R. D. And Newton, J. M. (1996). Enabling time-based strategy through logistics- using time to competitive advantage. Logistics Information Management, 9, 32-38.

Zhang, D. (2006). A network economic model for supply chain versus supply chain competition. Omega The International Journal of Management Science, 34, 283-295.

Table 1. Difference between competition and competitiveness.

\begin{tabular}{lcc}
\hline & Competitiveness & Competition \\
\hline Scale & Relational & Absolute \\
Focus & Macro & Micro (Typically) \\
Skill (deftmess) & Ability & Capacity \\
Nature & Static/State (of affairs) & Stochastic/Dynamic \\
\hline
\end{tabular}

Table 2. Competition theories against supply chain criteria.

\begin{tabular}{lccc}
\hline & R-A theory & Economic theory & Ecological theory \\
\hline Multi-dimensionality & & & $\checkmark$ \\
Process Orientation & $\checkmark$ & $\checkmark$ & $\checkmark$ \\
Emergence & $\checkmark$ & $\checkmark$ & $\checkmark$ \\
\hline
\end{tabular}

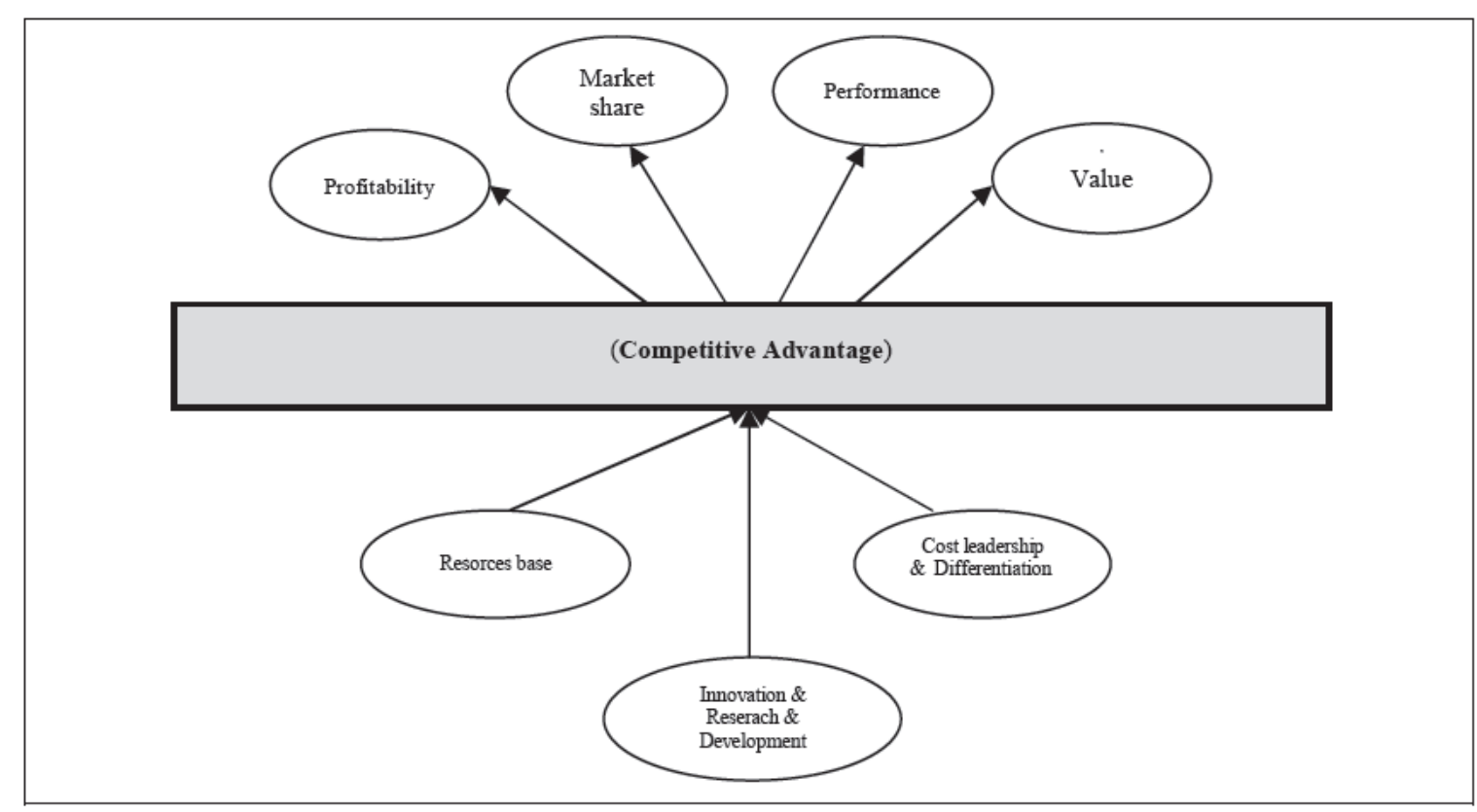

Figure 1. Competitive advantage 


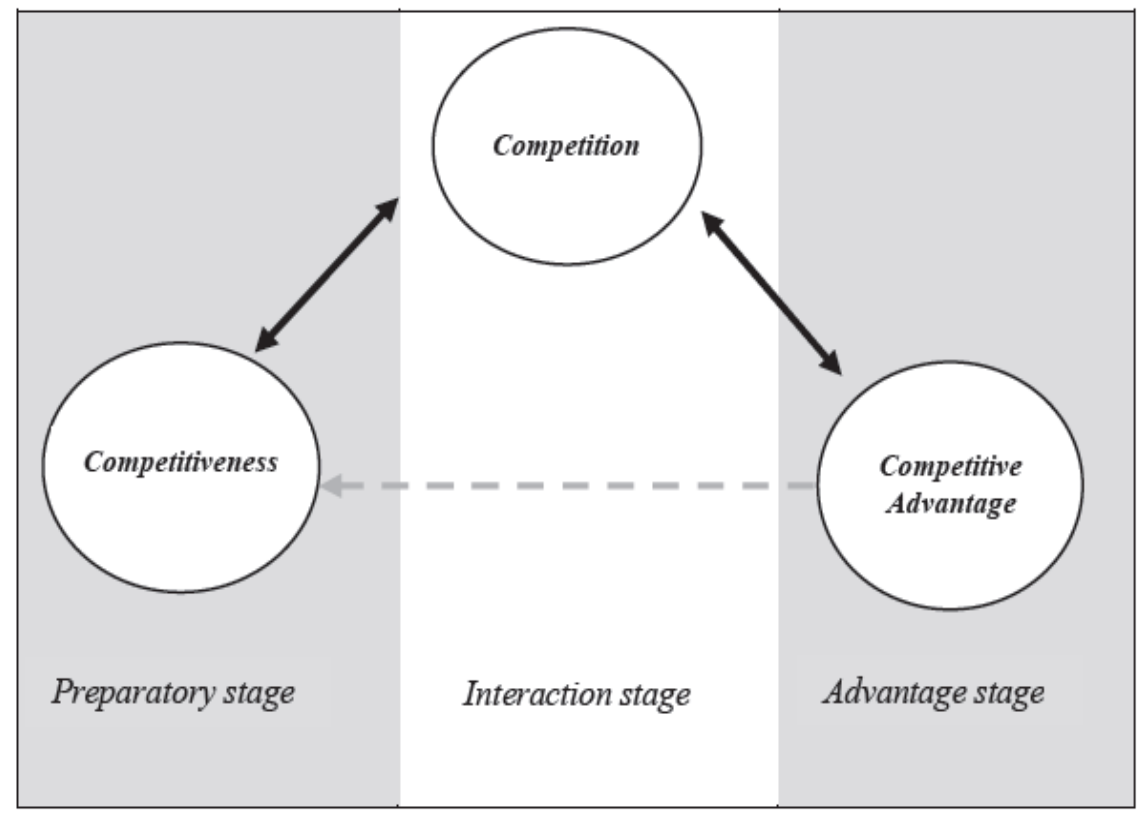

Figure 2. Relationship between competition, competitiveness and competitive advantage

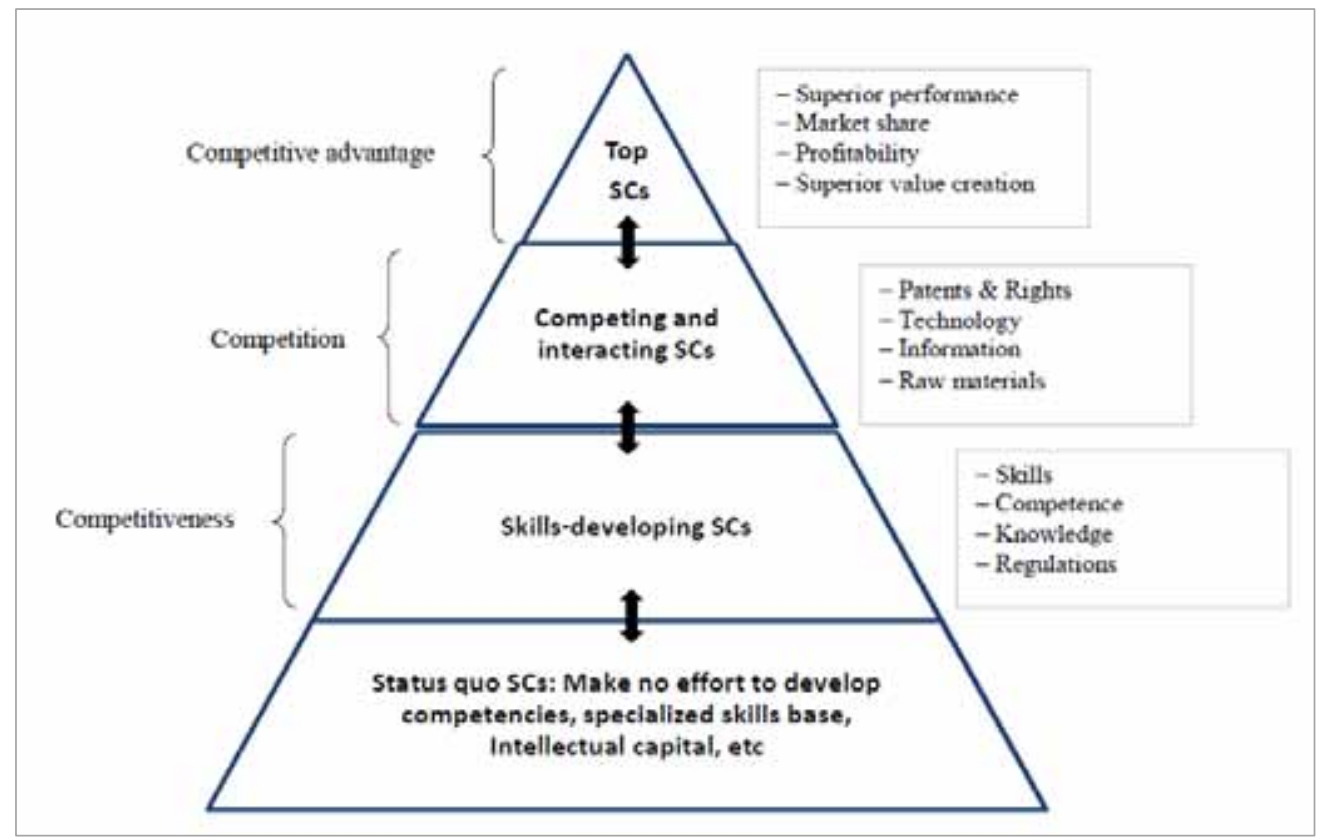

Figure 3. Supply chain competition pyramid 